\title{
THE RE-ACTUALIZATION OF ISLAMIC LAW: Munawir Sjadzali and the Politics of Islamic Legal Interpretation under the New Order Indonesia
}

\section{Cipto Sembodo}

An MA Student at the Graduate Programme of the State Islamic University

Sunan Kalijaga, Yogyakarta.

الملخص

يناقش هذا البحث عن فكرة إعادة فعالبة الفقه الإسلامي بإندونبيسيا التسي طرحها منور

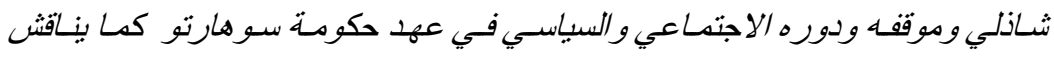

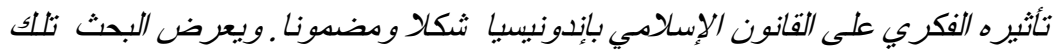

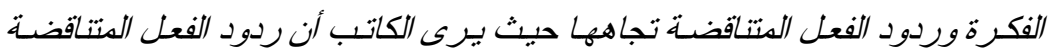

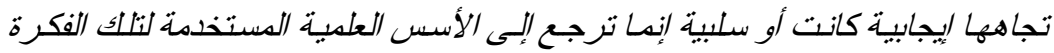

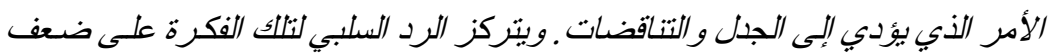

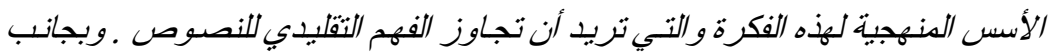

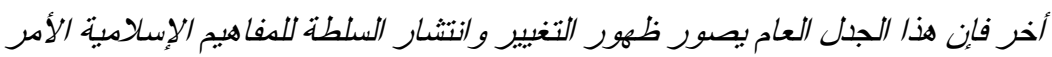
الذي يؤدي إلى عدم /حتكار فهم الفقه الإسلامي على رجال الدين الدعروفين تقلبيا باسم

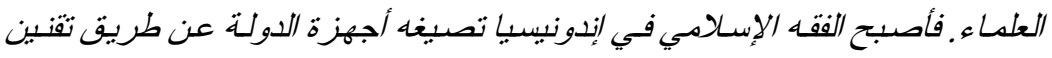

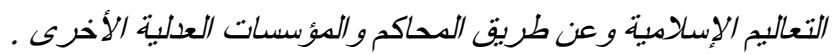

\section{Abstrak}

Artikel ini mendiskusikan reaktualiasi bukum Islam di Indonesia, gagasan, posisi, dan peran sosial politik Munawir Sjadzali dalam perpolitikan Orde Baru, serta pengarubnya terhadap bentuk dan isi bukum Islam. Setelah deskripsi tentang latar belakang kehidupan, karier 
serta pencarian intelektual Munawir, didiskusikan gagasan reaktualisasi dan polemik yang menyertainya. Penulis berargumen bahwa persoalan metodologilah yang sesunggubnya menyulut perdebatan. Keberatan banyak. pibak tertuju pada lemabnya dasar metodologis gagasan reaktualisasi yang ingin melampaui batasan tafsir teks tradisional. Di samping itu, debat publik ini juga menggambarkan adanya perubahan dan penyebaran otoritas keagamaan dalam bukum Islam. Sebagai akibatnya, bukum Islam tidak lagi menjadi monopoli kaum agamawan yang secara tradisional disebut ulama. Kini, ia direformulasi oleh organ-organ negara melalui legislasi aturan-aturan Islam, para hakim dan institusi peradilannya.

Keywords: Sjadzali, reactualization, Islamic law, New Order Indonesia.

\section{A. Introduction}

It goes without saying that Munawir Sjadzali has played a significant role both as a progressive Muslim thinker interested in the field of Islamic law, and as the leading figure created a new relationship between Islam and the state in Indonesia's New Order. Effendy's essay is of a work representing several studies on Munawir's ideas which have contributed to the harmonious relationship between Islam and the state. ${ }^{1}$ Other studies focus on Munawir's philosophical ideas as applied to Islamic law which has prompted him to suggest reforming, such matters as the Islamic law on inheritance. Michael Feener's works is, indeed, of the latest study of Munawir. ${ }^{2}$ Feener places Munawir in the specific context of the modern development of Islamic jurisprudence in twentieth-century Indonesia. He deals with the discourse on Islamic law, but the focus is not at providing answers to

${ }^{1}$ Bahtiar Effendy, "Islam and the State in Indonesia: Munawir Sjadzali and the Development of a New Theological Underpinning of Political Islam", in Studia Islamica Indonesian Journal for Islamic Studies, p. 110-117; Muhammad Wahyuni Nafis, et.al (eds.), Kontekstualisasi Ajaran Islam 70 Tahun Prof. Dr. H. Munawir Sjadzali,MA. (Jakarta: IPHIParamadina, 1995), p. 401-422; Faisal Ismail, "Munawir Sjadzali dan Pemikiran Politik Islam Kontemporer di Indonesia”, Mukaddimah, No. 3, July, 1997, p. 31-47.

${ }^{2} \mathrm{R}$. Michael Feener, Developments of Muslim Jurisprudence in Twentieth Century Indonesia, Ph.D. dissertation submitted to Boston University, 1999. 
the question of Munawir's specific ideas and his contributions to the power-Islamic legal knowledge relationship under Indonesia's New Order. What Feener does is to draw attention specifically on developments relevant to the area of Islamic legal theory, rather than theology or political and social thought. ${ }^{3}$

So far, little is known about Munawir's concerns for or his contribution to the social and political discourse which influenced Islamic law in Indonesia, its authority as well as its content and the textual formulation it takes. Consequently, his efforts to support the shifting paradigm of the politics of Islamic law remain a side issue, whereas this was an important problem and continues to become a divisive issue in the Muslim world. In many Muslim countries the issue influenced the content of Islamic law as well as its textual formulation that has been affected by reforms ideas. ${ }^{4}$

Just as in those Muslim countries, Islamic law reforms in Indonesia face the similar problems and consequences. Furthermore, the dilemma is complicated in a different way because of the pluralistic character of its demography, social structure, culture, religion, and politics. Therefore, in keeping with the above-mentioned issues, as John Bowen says, it has created new contexts and institutions for debates about transcendence and comprehensiveness. ${ }^{5}$

This essay comes to examine interpretations and discourses of Islamic law disseminated under the New Order regime. To deal with,

${ }^{3}$ See ibid., p. x, xi-xvii.

${ }^{4}$ This has actually been the case of Turkey, for example, that places its judicial reforms entirely in the programme of secularization. The result is undoubtedly secularization of Islamic law. See Murteza Bedir, "From Fikih to Law: Secularization through Curriculum", Journal of Islamic Law and Society, Vol. 11, No. 3, 2004, p. 378-401. Morocco has been conducting its judicial reforms in rather different way which evokes both confrontation and accommodation of fiqh and French modern code. See Léon Buskens, "Islamic Commentaries and French Codes: The Confrontation and Accomodation of Two Forms of Textualization of Family Law in Morocco", in Henk Driessen (ed.), The Politics of Ethnographic Reading and Writing: Confrontations of Western and Indigenous Views (Fort Lauderdale: Plantation, 1993), p. 65-100.

5John R. Bowen, "Legal Reasoning and Public Discourse in Indonesian Islam", in Dale F. Eickelman and Jon W. Anderson, New Media in the Muslim World the Emerging Public Sphere (Bloomington \& Indianapolis: Indiana University Press, 1999), p. 86. 
it explores mainly the ideas of and contributions by Munawir to social and political discourse of Islamic law in the Indonesian legal system. The subject to be discussed focuses on the reform ideas Munawir put forward and the various roles he has undertaken. In particular, the analysis is given to dismantling state interests in transforming Islamic law from its textual formulation of origin in the traditional-individual Islamic jurisprudence (fiqh), produced by Muslim jurists (fuqahā') into state-law made by the political decision of the state or government and enacted through modern legislation, of which Munawir was a part, such as the Religious Court and the Compilation of Islamic law, known as Kompilasi Hukum Islam di Indonesia (KHI).

In the following pages, this essay tries to provide answers to some questions, namely i) what type of Islamic legal knowledge has Munawir really tried to apply in Indonesia? ii) what is the relationship, between the type of Islamic legal knowledge he has suggested applying and the power of which he was a part?

\section{B. Munawir Sjadzali: His Life, Career and Intellectual Quest}

Munawir Sjadzali was born on November 7, 1925 in the hamlet of Karanganom, part of the larger Klaten regency, Central Java. "He was just a village boy with nothing extraordinary about him", one of his contemporaries says. ${ }^{6}$ But his tireless efforts to educate himself have led him to become a leading Muslim intellectual and a reformer in religious thought and politics. In the course of his career, he served two terms as the Minister of Religious Affairs in the New Order government. He passed away on Friday morning July 232004 in Pondok Indah Hospital, Jakarta, after suffering complications following an illness at the age of $79 .^{7}$

Munawir's father, Abu Aswad Hasan Sjadzali was thoroughly educated in religious sciences. He had studied in many traditional pesantrens (Indonesian traditional Islamic boarding schools), such as

${ }^{6}$ Munawir Sjadzali, "Dari Lembah Kemiskinan", in Muhammad Wahyuni Nafis et.al. (eds.), Kontekstualisasi Ajaran Islam, p. 6.

7"Ensiklopedi Tokoh Indonesia", bttp://www.tokohindonesia.com/m/ munawir-sjadzali/index.shtml, accessed at 16-9-2004, p. 1. 
"Jamsaren" in Solo, "Tebu Ireng" in Jombang and "Termas" in Pacitan. He was also an adherent of the Tariqah of Sazaliyah and was actively involved in many organizational activities and was especially interested in progressive Islamic ideas. But his mother, because of the social and cultural conditions at that time, was not educated in any pesantren or school. ${ }^{9}$ It is in this religious milieu that Munawir grew up. This religious upbringing very probably influenced his ideas for the next 40 years to come. ${ }^{10}$ Indubitably, it was his father who exerted a great influence on building his personality. According to Munawir, it was his father's simplicity, integrity, and self-confidence that served as a model for the personality traits that he continued to display throughout his life. ${ }^{11} \mathrm{He}$ completed primary school in his village, Karanganom in 1938. Then he continued his secondary school in Solo, about 30 kilometres due east of Klaten. He spent one year at an Islamic secondary school called "Al-Islam" (1939) before he was able to study at "Mamba'ul 'Ulum"12 in which he finally completed his secondary or junior and senior high school in 1943. This formal education provided Munawir with in-depth insights into the religious knowledge.

The physical struggle for Indonesian independence was a crucial phase. It was actually the period in which Munawir began to deal with the real problems of Indonesian and Islamic politics, conceptually as well as practically. It was the period when he become acquainted with

${ }^{8}$ Ibid., p. 7.

${ }^{9}$ Ibid.

${ }^{10}$ Hasbullah Mursyid, "Menelusuri Faktor Sosial yang Mungkin Berpengaruh", in Muhammad Wahyuni Nafis, et.al. (eds.), Kontekstualisasi Ajaran Islam, p. 188-195.

${ }^{11}$ It was to his father that Munawir Sjadzali often referred all the wisdom words to tell. See ibid., p. 14, 15 and 16.

${ }^{12}$ "Mamba'ul 'Ulum" is an Islamic school established by Sri Susuhunan Pakubuwono X, Surakarta in 1905, and initially aimed at providing candidate pengbulu (the traditional Javanese religious court judge) with better education. It is often considered as a pioneer of Islamic modern school for it included some aspects of the western education system in its curriculum. It consists of the primary, secondary and senior high school. See Karel A. Steenbrink, Pesantren Madrasah Sekolab Pendidikan Islam dalam Kurun Modern (Jakarta: LP3ES, 1986), p. 35-36. For detailed information see Muhamad Hisyam, Caught Between Three Fires The Javanese Pengulu Under The Dutch Colonial Administration (Jakarta: INIS, Vol. 37, 2001), p. 78, 140-145. 
many Indonesian Muslim intellectuals and political leaders, such as Soekarno and Munawar Cholil..$^{13}$ This was when for the first time he tried to come to grips with the relationship between Islam and the state, something that has occupied a considerable amount of his attention from then until nowadays, by writing a book entitled "Mungkinkah Negara Indonesia Bersendikan Islam?" (Is It Possible for Indonesian State to Be Based on Islam?). ${ }^{14}$

This was, I would say, the first intellectual creativity he had that kept him intellectually occupied the time he wrote the just-mentioned book in 1950s until the New Order were in power..$^{15}$ This was a turning point that radically changed Munawir's own life, and led him to work at the Department of Foreign Affairs. He began his career as a staff member of the Arab/Middle East section, and was appointed to work in Arab countries.

This gave him the opportunity to access such Islamic sciences as exegesis (tafsir), Islamic tradition (badith) and Islamic jurisprudence (figh). His competence in the Arabic language also ensured that the job he was in charge was done effectively. ${ }^{16}$ Some years later, when he

${ }^{13}$ Munawar Cholil, a Javanese by origin who lived in Semarang, the capital of Central Java was a very well-known Indonesian Muslim intellectual and reformer of Islamic thought at the beginning of nineteenth century. For further information see Taha Hamim, Moenawar Chalil's Reformist Thought: A Study of an Indonesian Religious Scholars (1908-1961), Ph.D. Dissertation, McGill University, Montral Canada, 1996. Brief analysis of the possible influence of Munawar Cholil's ideas on Munawir Sjadzali is given by Hasbullah Mursyid, "Menelusuri Faktor Sosial Yang Mungkin Berpengaruh", p. 195-198.

${ }^{14}$ Munawir Sjadzali, “Dari Lembah Kemiskinan”, p. 45.

${ }^{15} \mathrm{Hatta}$, the first vice president of the Republic of Indonesia praised this book for not being a cliché. See Ibid. The issue itself at that time had already been controversial as demonstrated in the parliamentary debates on the ideological basis for the country in 1945, and 1959 respectively. For more information see B.J. Bolland, The Struggle of Islam in Modern Indonesia (The Hague: Martinus Nijhoff, 1982), p. 15-99. See also Ahmad Syafi'i Maarif, Studi tentang Percaturan dalam Konstituante Islam dan Masalab Kenegaraan (Jakarta: LP3ES, 1985). Again, in 2000 the parliamentary debate on the same issue took place. The debates over the issue see A. Syafi'i Maarif, et.al, Syariat Islam Yes Syariat Islam No Dilema Piagam Jakarta dalam Amandemen UUD 1945 (Jakarta: Paramadina, 2001).

${ }^{16}$ See Nurcholish Madjid, "Prof. Dr. Munawir Sjadzali: Antara Diplomasi dan Tugas Kyai”, in M. Nafis et.al. (eds.), Kontekstualisasi Ajaran Islam, p.163-168. 
was appointed to work in the United Kingdom and the United States, he continued his studies at Western universities. He took a Diplomatic and Counsellor Course at the University of Exeter, Great Britain, in 1953-1954. Five years later (1956-1959) he, again, continued his studies at the Georgetown University, USA, where he earned his MA degree in political philosophy with great interest in the Indonesian political realm as the main focus. He was particularly advanced in the Islamic political sciences, as his just book unrequitedly demonstrates. This main concern was systematically developed when he studied the science of politics at Georgetown University. It is elaborated in his M.A. thesis entitled Indonesia's Muslim Parties and Their Political Concepts. His other books on politics are Islam and Governmental System: Teaching, History, and Islam: Realitas Baru dan Orientasi Masa Depan Bangsa, [Islam: New Reality and the Orientation for People's Future].

\section{Public Debate of the "Re-actualization" and the State Interests}

It is the re-actualization that has become the trademark of Munawir, along with all the works he contributed to Islamic legal knowledge during his tenure as the Minister of Religious Affairs. This is also one central theme that depicts the discursive corpus of Islamic law under Indonesia's New Order.

The re-actualization of Islamic teachings has been the most talked theme and issue of Islamic law renewal in twentieth century Indonesia and it was initiated by Minister of Religious Affairs, Munawir Sjadzali. He himself acknowledges that this idea had actually been introduced in various local forums and also abroad since the beginning of the 1985. The responses it elicited were normal. Only after it was presented at Paramadina on November 28 1986, did the idea of the reactualization spread to the Indonesian public at large, not without considerable controversy. ${ }^{17}$

\footnotetext{
${ }^{17}$ Munawir Sjadzali, "Dari Lembah Kemiskinan", p. 87. One version of the text in which he proposed publicly his ideas can be seen in Munawir Sjadzali, "Reaktualisasi Ajaran Islam", published first as articles-collection book in Iqbal Abdurrauf Saimima, Polemik Reaktualisasi Ajaran Islam (Jakarta: Pustaka Panjimas, 1988). Later on it was reproduced in Munawir Sjadzali, Islam Realitas Baru, p. 16-26; and Eddi Rudiana Arief
} 
The issues that attracted him most were various. Initially, he centred his proposal for re-actualization on the three issues of bank interest, the Islamic law of inheritance, and the laws of Islam dealing with slavery. However, on many latter occasions, he mentioned another issues such as Islamic taxation (zakāh) and the headscarf (jilbāb). ${ }^{18} \mathrm{He}$ also came to question such issues to the relevance of modern social life. All of these issues were discussed and criticized using the viewpoint of Islamic jurisprudence (fiqh).

What Munawir meant by the re-actualization of Islamic law was to modify and to contextualize certain religious precepts and practices in accordance with universal values of justice. ${ }^{19}$ Pleading for this reactualization, he mentioned the practices of the second Chaliph, 'Umar ibn al-Khattab, who departed from a textual understanding of the Qur'an in applying its prescriptions. Munawir's re-actualization, therefore, suggests taking advances of contextual interpretation instead of literal understanding of the Qur'an as a basis for legal decisions. In this light he advances the use of abrogation (naskh) and the purpose of the shari'ah (maqassid al-shari'ah) to legitimize his re-actualization, which sometime departs from some Qur'anic verses. ${ }^{20}$

The terms that Munawir used are familiar to those used in Islamic jurisprudence such as naskh and maqäsid al-shari'ah. But it should be noted here that what he meant by such terms went far beyond the definition of the concept. An examination of his ideas concerning nask $h$

(ed.), Hukum Islam di Indonesia Pemikiran dan Praktek (Bandung: Rosdakarya, 1994), p. 83-94. Other versions of the texts that he previously discussed in various forums include "Pembangunan Hukum dan Perkembangan Fiqh di Indonesia", a keynote speech paper for the seminar held by IAIN Sunan Ampel, Surabaya on February $4^{\text {th }}$, 1985. See Munawir Sjadzali, Islam Orientasi Baru, p. 52- 60; and "Syariah: A Dynamic Legal System", Keynote address to the international seminar on shariah and codification, Colombo, December $16^{\text {th }}, 1985$. Himpunan Pidato Menteri Agama RI H. Munawir Sjadzali Oktober 1985-September 1986, Biro Hukum dan Humas Departemen Agama RI, p. 215222. It is also reproduced in Munawir Sjadzali, Islam Orientasi Baru, p. 9-15.

${ }^{18}$ Munawir Sjadzali, "Gejala Krisis Integritas Ilmiah di Kalangan Ilmuwan Islam”, Speech paper on student graduation of IAIN Syarif Hidayatullah Jakarta, July $23^{\text {rd }}$, 1987. In Islam Orientasi Baru, p. 2, 6-7.

${ }^{19}$ Ibid.

${ }^{20}$ See Munawir Sjadzali, “Ijtihad dan Kemaslahatan Umat”, p. 118-119, 122. 
clearly revealed that he used the term to support the possibility of abandoning purely Qur'anic texts themselves when they come into conflict with the needs of the time, an idea that was never intended by the term itself. ${ }^{21}$

As far as the proposal for the re-actualization of Islamic law is concerned, it can be defined as a departure from what the revealed texts clearly and explicitly say, actually, the very matter that has given rise to the public controversies and polemics. Although he used the terms that are familiar to students of classical Islamic jurisprudence, from the point of many Muslims views, the way he applied such concepts was perceived to be too liberal or even out of context. This is why many Muslims who disagreed with him were of the opinion that Munawir's proposal for the re-actualization was a mere fabrication. Sometimes they were so far as to think it endangered scriptural bases and understandings and denigrated Muslim religious believes.

Responses to and criticisms of the re-actualization, from those who agree as well as disagree, focus mostly on the methodological aspects that Munawir used in a very liberal manner. The general response was to hold what the revealed text says explicitly and not to depart from it. Some others emphasized their criticisms at the empirical levels upon which Munawir based his re-actualization, Among such figures were Azhar Basyir and Yahya Harahap. ${ }^{22}$

It was not without reason that Munawir proposed this idea of re-actualization of Islamic law however. He was deeply aware that there were a plethora of new circumstances and modern challenges that Islamic law had to deal with. These challenges are indeed formidable and also complex. He believed that this was the best way

${ }^{21}$ Ibid.

${ }^{22}$ Such critics have been published in two books: Iqbal Abdurrauf Saimima, Polemike Reaktualisasi Ajaran Islam and Haidar Bagir and Syafiq Basri (eds.), Ijtihad Dalam Sorotan. See also Muhammad Wahyuni Nafis et.al. (ed.) Kontekstualisasi Ajaran Islam, p. 249-332. For further general analysis see Michael Feener, Developments of Muslim Jurisprudence in Twentieth Century Indonesia, Ph.D Dissertation submitted to the Boston University, 1999, p. 164-180. Bowen also discusses it in a rather different theme of gender equality. See John R. Bowen, “Qur'an, Justice, Gender: Internal Debate in Indonesian Islamic Jurisprudence”, in History of Religion, Vol. 38, No. 1, 1998, p. 73-78. 
to preserve the universal validity of Islamic teachings and their system of values, including those embodied in the shari' $a b$, in this fast changing world, full of social and cultural diversities. ${ }^{23}$ In this light he believed that shari'ah is truly a dynamic legal system, with a high degree of adaptability. ${ }^{24}$ It was reasonable therefore to assume that the answers to these challenges would be found in ijtihäd that Muslims resort to in response to the needs of their specific time and localities.

However, apart from the academic and intellectual discussions stating Islamic law needed fresh interpretations, the significance of the re-actualization for the political discourse of Islamic law in Indonesia lies beyond this sort of considerations. In my view, this is actually an important point that needs to be paid careful attention because of the fact that it was developed indirectly to suit the new social circumstances under the New Order government's political orientation namely the development of the economy and the attainment of political stability. Alongside this political orientation it was essential to develop the legal system so that it could maintain national unity and serve cultural and religious diversities.

Bearing this in mind, it is important to note that the ideas of the re-actualization were introduced at the time the government launched a joint-project between the Ministry of Religious Affairs and the Supreme Court to produce a compilation of Islamic law. ${ }^{25}$ Given the fact that many different practices of Islamic law already present in Indonesian Muslim society sometimes depart from normative prescriptions, especially in the field of inheritance, the government's interest was to make sure that such realities would not be overlooked so that the compilation would have a practical significance. For this reason, he said, the deviations in the practices of Islamic law of inheritance were relevant to the discussion. This is why inheritance assumed a central place among the issues that were extensively debated in the polemics of the re-actualization of Islamic law.

\footnotetext{
${ }^{23}$ Munawir Sjadzali, "Syariah: A Dynamic Legal System”, in Islam Realitas Baru, p. 10.

${ }^{24}$ Ibid.

${ }^{25}$ Munawir Sjadzali, "Dari Lembah Kemiskinan”, p. 95. Idem, “Syariah: A Dynamic Legal System”, p. 10.
} 
The Compilation Project was a highly significant step, but even the more important was the fact that President Soeharto approved the idea of the re-actualization of Islamic law. In September 1987, Munawir set out his ideas on the re-actualization which he delivered at the Syarif Hidayatullah State Institute for Islamic Studies, which had been controversial among Muslims, to the President. ${ }^{26}$ On this occasion Munawir explained that a literal understanding would be an obstacle to and would essentially endanger the development of society. Exceeding all expectations, President Soeharto approved his ideas of the contextual interpretation of Islamic teachings and advised the Minister to "use the IAIN to produce scholars who will agree with your way of understanding". ${ }^{27}$

Perhaps that is one aspect that clearly helps to explain the state political interest in the re-actualization. Later, this was supported by prominent figures in government circles, including the Council of Indonesian Ulama (MUI). The writing of Ibrahim Hosen demonstrates and his opinion in which he provides a public endorsement of the Minister's programme and ideas, embellished with extensive Arabic

\footnotetext{
${ }^{26}$ The text he means is "Gejala Krisis Integritas Ilmiah di Kalangan Ilmuwan Islam” Islam Orientasi Baru, p. 1-8.

${ }^{27}$ Munawir Sjadzali, “Dari Lembah Kemiskinan”, p. 96, 97. In the light of this advice Munawir himself actually had already paved the way toward "producing" new Muslim intellectuals by developing IAINs all over the country. Of particular interest is the shift in orientation of the IAIN from the al-Azhar University Egypt in the Middle East to the Western universities such as McGill University Canada, Leiden Universiteit the Netherlands, University of California Los Angeles and University of Chicago in the US. Later the influence of its alumni has been important in the understanding and applying the approaches and conceptual categories from the academic study of religion, and especially Islamic Studies, to the Indonesian public religious discussion. Federspiel calls these intellectual as "the state islamicists". See Howard Federspiel, "Islamic Values, Law and Expectations in Contemporary Indonesia", in Arskal Salim and Azyumardi Azra (ed.), Shari'a and Politics in Modern Indonesia (Singapore: ISEAS, 2003), p. 199-201. Informative accounts of their roles see Yudian W. Asmin (ed.), Pengalaman Belajar Islam di Kanada (Yogyakarta: Titian Ilahi Press, 1997). See also Fuad Jabali and Jamhari et.al. (eds.), LAIN dan Modernisasi Islam di Indonesia (Jakarta: Logos, 2002).
} 
quotations from the classical fiqh scholarship. ${ }^{28}$

All the above reasons show indubitably that Munawir played a decisive role in encouraging positive encounters between Islamic law and the state. It was Munawir himself, as Minister of Religious Affairs who made attempts to convince the state apparatus to adopt a positive relationship with, instead of taking a suspicious approach to Muslims and their aspirations for Islamic law. It was he who struggled from within to encourage Indonesian Muslims to think about Islamic law with a more rational and critical way of reasoning. In this way, he believed, Islamic law could be made relevant to the needs of contemporary society and could serve to boost modern development.

These are the messages that Munawir wanted to put forward. And, for this reason the re-actualization was considered to be an inwardlooking process criticizing Muslim religious teaching while at the same time paving the way to carry out other fundamental policies ${ }^{29}$ i.e. to bring Islamic law back into the Indonesian nation-state as long as it is in line with the state ideology and its legal systems.

\section{State Islamic legal Interpretation and the Public Faces of Islamic Law under the New Order in Indonesia}

This analysis of the state political discourse and interpretation of Islamic law under the New Order suggests that it is most obviously represented in two products of the state law, namely the 1989 Judicature Act passed by the House of Representatives (DPR) and the Compilation of Islamic Law enacted by Presidential Instruction. Indubitably in both of these, Munawir played critical roles and made invaluable contributions. As a matter of fact, these two state laws have brought about changes and departures of Islamic law at a practical

${ }^{28}$ See Ibrahim Hoosen, "Beberapa Catatan Tentang Reaktualisasi Hukum Islam”, in Muhammad Wahyuni Nafis et.al. (ed.) Kontekstualisasi Ajaran Islam, p. 251-258. See also Ibrahim Hosen, "Pemerintah Sebagai Madzhab", in The Journal of Pesantren, Vol. II, No. 2, 1985.

${ }^{29}$ Taufik Abdullah, "Menteri Agama Republik Indonesia: Sebuah Pengantar Profil Biografis", in Azyumardi Azra and Saiful Umam (eds.) Menteri-Menteri Agama RI Biografi Sosial-Politik (Jakarta: INIS, PPIM \& Badan Litbang Departemen Agama RI, 1998), p. xl. 
level as well as at the conceptual, transforming it from its classical fiqh form of origin to the modern form of statute or legislation.

Presumably this is the main goal that the state interpretation and discourse of Islamic law would like to convey. As we will see soon, this appears in the organization and practice of the religious court and in the textual formation of the compilation of Islamic law. To focus it inexorably on the point of the state Islamic law-making process, this discussion will only deal with important features which depict the new form of the practice of Islamic law that are alien to the classical Muslim jurisprudence.

\section{The Organization and Practice of the Religious Court}

The religious court and its incorporation into the state bureaucracy in Indonesia can be traced back to the Dutch colonial administration. The process began with a Dutch Royal Decree of 1882 No.152. Although this was not the first rule dealing with the institution of what was then called a religious court, it was an important decree because it defined for the first time the organization and practice of the religious court as it has prevailed down to the present days. ${ }^{30}$ The Decree formally stated that the religious court (priesterraad) would operate alongside the existing civil court (landraad) in Java and Madura. More importantly, it suggested that the religious courts were to consist of a penghulu, appointed by the civil court (landraad), and from three to eight members, with a minimum of three required for a quorum. ${ }^{31}$

This rule was diverged considerably from the common practice of what then called the religious court. Although the original functioning of this embryonic form of the religious court varied from

${ }^{30}$ The first rule dealing with the matters of the religious court was the Stb. 1835 no. 58. The Dutch Royal Decree of 1882 No. 152 consists of seven articles and was signed by the King Willem III on 19 January 1882. See Karel A. Steenbrink, Beberapa Aspek Tentang Islam di Indonesia Abad Ke-19 (Jakarta: Bulan Bintang, 1984), p. 217.

${ }^{31}$ Ibid. More detail analysis see Daniel S. Lev, Islamic Court in Indonesia: A Study in the Political Bases of Legal Institutions (Berkeley: University of California Press, 1972), p. 14. See also Mark Cammack, "Indonesia's 1989 Religious Judicature Act: Islamization of Indonesia or Indonesianization of Islam?”, Cornell Southeast Asia Programm, No. 63, 1997, p. 144-145. 
one region to another, it was presided over by on Islamic judge or penghulu appointed by the Sultan or by local aristocracy. ${ }^{32}$ This is to say that presumably prior to the Decree of 1882, the Religious Courts were traditionally single-judge, as was the case in Java. ${ }^{33}$ Actually this was the point that prompted Snouck Hurgronje to criticize this Decree, stating that this was not in accordance with the law of Islam and its common practices. The collegial character or jurist-system of the religious court was still alien to Muslim societies. ${ }^{34}$ From this point we may say, as Mark Cammack suggests, that the collegial system of the court was entirely a Dutch innovation. ${ }^{35}$

Apparently the functioning of the religious court as it was defined by the Decree of 1882 seems to have continued until the present day. Of course there were debates surrounding the foundation of this court, its status within prevailing legal system and its implementation in the real world of Muslim society. Such fuctions recurred in the time of the Dutch colonial administration and in the era of Indonesian independence as well. ${ }^{36}$ Indeed the court continued to work in its tried and tested way as set out in in the Decree of 1882 until the reforms of 1989. These short explanations perhaps give us ground to agree with Hooker's view that the system of the religious court in Indonesia was

\footnotetext{
${ }^{32}$ The original practices of this religious court differed from one region to another according to the extent of the influence and the strength of local customs. Daniel S. Lev, Islamic Court in Indonesia, p. 10-11.

${ }^{33}$ Ibid., p. 14.

${ }^{34}$ Karel A. Steenbrink, Beberapa Aspek, p. 221-222.

${ }^{35}$ Mark Cammack, "Indonesia's 1989 Religious Judicature Act: Islamization of Indonesia or Indonesianization of Islam?”, p. 144-145.

${ }^{36} \mathrm{In}$ the era of the Dutch administration, there were at leas three rules dealing with the religious court. They are Stb. 1882, Stb. 1889, Stb. 1937. Since Indonesian independence there has been three rules at least pertaining to the religious court, such as the Statute of 1951, the Statute of 1957 and the Statute of 1979. For further detailed account of these rules see Daniel S. Lev, Islamic Court in Indonesia, p. 10-140. Mark Cammack, "Indonesia's 1989 Religious Judicature Act”, p. 144-152. See also M. Atho Mudzhar, Fatwas of The Council of Indonesian Ulama: A Study of Islamic Legal Thought in Indonesia 1975-1988 (Jakarta, INIS Vol. XVII, 1993), p. 31-49.
} 
the main legacy of the Dutch. ${ }^{37}$

The 1989 Judicature Act passed by the House of Representatives (DPR) did in fact confirm the above-mentioned practice. The function and content of this act was essentially procedural. ${ }^{38}$ As mentioned above, they were collegiate and had an appeal system (Articles 1-5). Moreover, as we can see from the 1989 Judicature Act, the most part of the provisions regulated the appointment of court officers and defined their functions (Articles 6-48). The way it works also relies on the secular model of tribunal. Article 54 of this act states that the religious court must follow the laws of civil procedure operating in the general court. They not allowed to reject any lawsuit brought by a litigant who seeks justice (Article 56), and they supposed to follow secular rules of describing and validating and filing judgments (Articles $55,57-64)$. This shows unequivocally that the religious court is based entirely on the modern Western model of a tribunal. It borrowed the formal apparatus of the civil court, from clothing and desks to the format of decisions. Hence, written and oral religious court decisions today strongly resembled those of the civil law courts. ${ }^{39}$

As a state product of legal policy on Islamic law, these features of the organization and practice of the religious court are somewhat strange. Because, while the 1989 Judicature Act provided the religious court with a strong political and legal acceptance in the nation state of Indonesia, at the same time it evoked a rather striking result. Undoubtedly it expanded and equalized the court's power, giving it more status and prestige, but it also has to be admitted that the act had only very little to do with and did little to include the substance of Islamic law. This is perhaps understandable for it only provides for procedural law. Unfortunately, this procedural law also seems to be restricted to the application of classical Islamic jurisprudence (fiqh).

${ }^{37}$ M.B. Hooker, “The State and Shari'a in Indonesia”, in Arskal Salim and Azyumardi Azra, Shari'a and Politics in Modern Indonesia (Singapore: Institute of Southeast Asian Studies, 2003), p. 34-35.

${ }^{38}$ Ibid.

${ }^{39}$ John R. Bowen, "Legal Reasoning and Public Discourse in Indonesian Islam", in Dale F. Eickelman and Jon W. Anderson, New Media in the Muslim World the Emerging Public Sphere (Bloomington \& Indianapolis: Indiana University Press, 1999), p. 91. 
Otherwise, it has adopted all the procedural law which is used in civil or general courts, with the exception of the procedures that have been ruled in the 1989, namely the procedure of Islamic divorces (Article 54). The classical Islamic rules of evidence, for example, were essentially changed. Article 87 on divorce on the grounds of fornication, zina, may be the only one which is closely related to Islamic rules of evidence. But, as the judge, Roihan Rasyid admitted this article is not easy to implement. ${ }^{40}$ It also important to note that the penalties such as stoning to death, rajm, and flogging, in the case of fornication are not applied. ${ }^{41}$

These features testify that it would not be far wrong to assume that instead of preserving Islamic classical jurisprudence, the tendency of the 1989 Judicature Act seems to be otherwise. It suggests making a kind of regulatory reforms. It means to be headed in the opposite direction it deals primarily with procedural rules, which theoretically do not affect the content of Islamic jurisprudence. However the practices it engender will be entirely new. So, some changes and reforms will be applied indirectly and prevail on the Islamic law practiced in the religious court. The practices of the religious court, therefore, will usher in changes and reforms in Islamic law which are characteristically Indonesian. Therefore, it is not surprising that Mark Cammack and Hooker find a host of peculiarities in divorce procedure with regard to classical Islamic jurisprudence, which Cammack characterizes as "Indonesian madhhab". ${ }^{42}$

Apart from changes in the practices of Islamic law brought by the 1989 Judicature Act, all the above features suggest a positive correlation with Munawir's discourse on the re-actualization. They fit positively in many ways with the basic idea of the re-actualization. This confirms Munawir's idea, for example, that Islamic law can be applied in flexible manner to fit in with specific condition in the social

${ }^{40} \mathrm{On}$ how difficult and complicated to deal with this process see Roihan A. Rasyid, Hukum Acara Peradilan Agama (Jakarta: Rajawali Pers, 2002), p. 137-192. also M. Yahya Harahap, Kedudukan Kewenangan dan Acara Peradilan Agama Menurut Undangundang No. 7 tabun 1989 (Jakarta: Pustaka Kartini, 1989), p. 322-330.

${ }^{41}$ Ibid., p. 177-178.

${ }^{42}$ Mark Cammack, “Indonesia's 1989 Religious Judicature Act”, p.162-166. M.B. Hooker, "The State and Shari'a in Indonesia", p. 34-36. 
and political context. Its political character, furthermore, increasingly signified the Islamic legal-political building provided by Munawir's introduction of Pancasila. Far more striking is to see that these features of changes and reformulations gained most of their common support from Islamic judges who were mostly reformist in orientation.

\section{Textual Formulation of the 1991 Compilation of Islamic law}

As equally important to Indonesian Islamic legal development as the 1989 Religious Judicature Act is the Kompilasi Hukum Islam di Indonesia (KHI), literally translated as the compilation of Islamic laws in Indonesia. This is one of many vehicles used by the Indonesian government to unify and codify Islamic law. This codification, utilized by judges in the religious court, was meant to serve as a reference guide in deciding cases. ${ }^{43}$ Before the enactment of the compilation, legal decisions made by Islamic judges in the religious court were based on thirteen fiqh books, as suggested by the circulation of the General Directorate of the Religious Court of the Department of Religious Affairs No. B/1/735 on 18 Februari $1958 .^{44}$

It against this background that the 1991 compilation of Islamic law signifies a new phase in the history of Islamic law in modern Indonesia. It is the substantive law as opposed to the procedural law of the 1989 Religious Judicature Act, which applies exclusively to family law matters in the religious court. In contrast to the 1989 Act which is legislation passed by the House of Representatives (DPR), the 1991 Compilation is a Presidential Instruction (Inpres) issued on

${ }^{43}$ Ahmad Imam Mawardi, "The Political Backdrop of the Enactment of the Compilation of Islamic Laws in Indonesia", in Arskal Salim and Azyumardi Azra, Shari'a and Politics, p. 125.

${ }^{44}$ These books are Bughyat al-Mustarshidin by Husain al-Ba'lawi, al-Farid by Shamsūrì, Fath al-Mu ìn by al-Malibāri, Fatḥ al-Wabhāb by al-Anșārì, al-Fiqh 'Al al-Madhähib al-Arba'ah by al-Jazirī, Hashiyah Kifayat al-Abyār by al-Bajūri, Mughni al-Mubtäj by Sharbinin, Qawānin al-Shar'iyyah by Sayyid Șadaqah Șan'ān, Qawānin al-Syar'iyyah by Uthmn Ibn Yahyā, Sharkh Kanz ar-Rāghibin by Qalyübi and 'Umayrah, Targhib al-Mushtaq and Tuhfah al-Mụtaj by Ibn Hajar al-Haytami. See Abdurrahman, Kompilasi Hukum Islam di Indonesia (Jakarta: Akademika Pressindo, 1992), p. 22. See also Mouhammad Atho Mudzhar, Fatwas of The Council of Indonesian Ulama, p. 37-38. 
June $111991 .{ }^{45}$ But precisely because of the legal form that the compilation assumes it can be considered to contribute a new tradition to Islamic legal literature. ${ }^{46}$

The 1991 Indonesian compilation of Islamic law differs from classical Islamic jurisprudence, figh, and it is also not legislation. But from the way it was formulated, it can be called a codification, or figh in the form of legislation, according to Bustanul Arifin ${ }^{47}$. This is why, though it is characterized as a mere compilation of opinions in fiqh books, the format and style of the 1991 compilation of Islamic law is that of code. It is divided into three books. Book One addresses marriage and divorce law. Book Two is about inheritance. Book Three deals with charitable foundations (waqf). The material is subdivided topically into books, chapters, and articles, beginning with a chapter addressing general provisions followed by chapters treating specific subject areas in each book.

${ }^{45}$ In the Indonesian legal system, a Presidential Instruction has a lower standing than a statute, but enjoys the all-important backing of the President.

${ }^{46}$ According to Mudzhar, there are at least four types of Islamic legal literature, namely books of Islamic jurisprudence (al-kutub al-fiqhiyyab), decrees of Islamic courts, law and regulation adopted by Muslim countries, and legal pronouncement of juris consults (fatwas), each of which subjects to socio-cultural and socio-political factors surrounding. See Mohammad Atho Mudzhar, Islam and Islamic law in Indonesia A SocioHistorical Approach (Jakarta: Office of Religious Research and Development, and Training, 2003), p. 94-104. In a rather different emphasize, Bowen suggests that those four types of institutions can, did, and do exist in many possible combinations. See John R. Bowen, "Shar's'a without Fiqh: the Anthropology of Law without Law? Reflection from France", Paper presented at the ISIM Workshop on the Athropology of Islamic Law (Leiden, March 14-16, 2003), p. 1. Given the fact that the compilation of Islamic law in Indonesia is different from any of the four, it is reasonable to say that the compilation contributes to a new form of Islamic legal literature.

${ }^{47}$ Bustanul Arifin, "Kompilasi: Fiqh dalam Bahasa Undang-undang", in Journal of Pesantren, No. 2, vol. II, 1985, p. 25-30. The task of the compilation consisted of five steps. The first was the examination of fiqh books. The second step was interviews with a number of ulamas. The third step was the examination of the jurisprudence of the religious courts. The fourth step was a comparative study of other Muslim countries. The fifth and the final step was the workshop of the ulama was held in February 2-5, 1988. For detail information see further Bustanul Arifin, Pelembagaan Hukum Islam di Indonesia Akar Sejarah dan Prospeknya (Jakarta: Gema Insani Press, 1996), p. 31-52. Abdurrahman, Kompilasi Hukum Islam, p. 36. 
As long as it is placed in the context of the implementation of Islamic law through the institution of Islamic courts the function of the 1991 Compilation is indeed obvious. It is a logical consequence of a certain need felt by the institutionalized religious court. It is one of three pillars which the religious court needs to have, namely legal reference. ${ }^{48}$ Legal reference is the primary need for a modern court. It serves as the basis upon which any legal decisions in the religious court are made.

In addition, being the source of legal reference in the religious courts, at the same time the compilation the aim was to introduce the same perceptions of Islamic legal implementation and to prevent disparities in legal decisions. ${ }^{49}$ The use of figh books as legal references in deciding cases had given rise uncertainty in the implementation of Islamic law in the religious courts. Therefore, as was hoped, shortly after it came into effect, it began to be cited as the basis for decisions, supplementing or replacing citations from classical figh texts. Yahya Harahap argues that the role of fiqh books in the implementation of Islamic law in Indonesia slowly but surely will be left behind. ${ }^{50}$ Their role is only as a material for orientation and doctrinal study of Islamic law rather than as a reference in deciding cases in the religious court.

This shifting paradigm from the use of figh books as legal reference in the religious court to the use of the 1991 Compilation is certainly the most important phenomenon in Indonesian Islamic legal development. Many Indonesian Islamic legal experts, some of them supreme court judges have come to believe that the use of the compilation will lead to the certainty in the law, which was the goal of the government. It will solve the common problem of legal disparities (khiläfiyyah) among Indonesian Muslim people who apply to the process of judicial decision. In the context of Indonesian legal discourse, the

${ }^{48}$ The other two pillars are the institution of court in which law is conducted and the officers and judges who superintend judicial activity. Bustanul Arifin, Pelembagaan Hukum Islam di Indonesia, p. 31-52.

${ }^{49}$ Muhammad Yahya Harahap, "Informasi Kompilasi Hukum Islam: Mempositifkan Abstraksi Hukum Islam”, in Cik Hasan Bisri (ed.), Kompilasi Hukum Islam dan Peradilan Agama dalam Sistem Hukum Nasional (Jakarta: Logos, 1999), p. 31-32.

${ }^{50}$ Ibid. 
compilation is even considered positivized Islamic law. This acceptance means it can be enforced by the state legal apparatus. There are those who as far as to suggest that the need of such compilation is indeed an extension of Islamic legal thought and its history. It is perpetuation of the Ibn al-Muqaffa's suggestion to al-Manșūr (754-775), an Abbasid Caliph, on the making of an Islamic codification. ${ }^{51}$

Apart from the certainty in law that the 1991 compilation is believed to achieve, the downside of the Compilation is that the textual formulation of the compilation is still poor of analysis. The use of the compilation instead of figh books indeed reflects the contradiction or at least contestation between figh books and the compilation or legislation in the implementation of Islamic law in Indonesia at the conceptual and the practical level. Recent studies on the practical application of the compilation show that many judges still use and cite figh texts and their arguments in deciding the cases submitted to them. ${ }^{52}$ To some extent, this finding also supports Bowen's analysis which uncovers the confrontation between fiqh and positive law in Indonesian public legal reasoning. ${ }^{53}$ As a matter of fact, this contestation or even confrontation to use Bowen's term, accompanied the discussion of the compilation, which according to Abdul Gani, reflects the domination of figh in the content of Islamic law discourse in Indonesia. ${ }^{54}$

But precisely because of this contestation, I would argue, the compilation has gained in significance. At the same time, it is also the specific context which explains the type of Islamic legal discourse and knowledge that the state would like incorporate in its law and political

${ }^{51}$ See for example Bustanul Arifin, "Kompilasi: Fiqh dalam Bahasa Undangundang", in Pesantren, No. 2, vol. II, 1985, p. 25-30. Muhammad Yahya Harahap, "Informasi Kompilasi Hukum Islam:" p. 31-32. Wahiduddin Adams, "Legislasi Hukum Islam dalam Perspective Fiqh", in Pesantren, No. 2, vol. II, 1990, p. 19-28.

${ }^{52}$ See Acep Zoni Saiful Mubarok, Kompilasi Hukum Islam sebagai Sumber Hukum (Study kasus di Pengadilan Agama Tasikmalaya), MA Thesis submitted to the Graduate Programme of the State Institute for Islamic Studies Sunan Kalijaga Yogyakarta, 2000.

${ }^{53}$ See John R. Bowen, "Legal Reasoning and Public Discourse in Indonesian Islam", p. 97. Idem, Islam, Law and Equality An Anthropology of Public Reasoning (New York: Cambridge University Press, 2003), p. 257.

${ }^{54}$ Abdul Gani Abdullah, Pengantar Kompilasi Hukum Islam dalam Tata Hukum Indonesia (Jakarta: Gema Insani Press, 1994), p. 24. 
order. Again and again Munawir became the main icon who played a central role and made starling contributions. Along with the Munawir's re-actualization, the Compilation of Islamic Law came into being as representative of the spirit of reforms and the renewal of Islamic law of Indonesia in the twentieth century. Moreover, the compilation has been often claimed as the product of the consensus (ijma $\bar{a}$ ) of Indonesian ulama. ${ }^{55}$ In addition, despite the fact that the compilation is generally traditional in character, ${ }^{56}$ it has brought about changes to fit with the current need of specifically Indonesian values in Islamic law, such as conditional repudiation, common property in marriage, obligatory bequest for adoptive children and parent, and the like. What is obvious from the process of reforms attached to the compilation is the departure from using classical fiqh prescriptions to accommodate prevailing customary values and practices. It is this feature indeed which represents what has gained fame as "Indonesian fiqh".

Another matter that has been neglected is the fact that the compilation is formulated in an easy-to-understand and ready-to-use style of writing. It also uses Indonesian language. Like other secular legislation, there is nothing striking to analyse in any depth. The use of such a style of writing and the choice the nationally used language is a common feature, even an obvious one from the view point of legal drafting theory. But these have further consequences if they are viewed from its relationship with legal and religious authority.

${ }^{55}$ Bowen critically analyses this claim as it precisely illustrates the contradiction between the compilation and figh. While fiqh is in itself full of disagreements, the compilation represents well ordered statutes of the state. On this contradiction, see John R. Bowen, "Legal Reasoning and Public Discourse in Indonesian Islam", p. 97101. Idem, Islam, Law and Equality in Indonesia, p. 257. In addition to what has been stated by Bowen, the consensus of Indonesian jurist (ijm $\bar{a}$ ) in fact hardly holds water because of the fact that there are still many opinions questioning the contents of the compilation such as Roihan A. Rasyid, "Pengganti Ahli Waris dan Wasiat Wajib" in Cik Hasan Bisri (peny.), Kompilasi Hukum Islam, p. 81-98.

${ }^{56}$ Part of the contents of the compilation is considered traditional mainly because they still treat unequally male and female relationship in Islamic law of bequest. See John R. Bowen, "Legal Reasoning..." Ibid., p. 99-100. See also Mark Cammack, "Inching toward equality: Recent developments in Indonesian inheritance law", in Women Living under Muslim Laws, Dossier 22, November 1999, p. 8-11. 
Compared with figh textual formulation which uses Arabic and is written in a highly advanced form of discussion, the compilation represents an enormous change. It is easy to read, and even ready to use by judges without any need to consult to figh texts. This means the compilation is actually intended for public consumption. It directly invites public participation and a public reader shifts to find out what Islamic law looks like from the view point of the state. ${ }^{57}$ This is true of the government itself which has been deliberately promoting the socialisation of the compilation through any vehicles, government offices as well as independent organizations, such as the Muhammadiyah and the Nahdlatul Ulama'. It has also been introduced to and included in the curricula of universities all over the country. Even more importantly and interestingly, it has been studied in the Faculty of Shari'ah of the State Institute for Islamic Studies all over the country along with other figh texts. ${ }^{58}$ One would expect that all these features clearly suggest state-sponsored Islamic legal knowledge. Therefore, in the long term it may constitute the state production of Islamic legal knowledge.

These features of the compilation, of course, are not to say that it is less scholarly and academic than popular. The truth is indeed otherwise, it employs highly sophisticated Islamic legal theories and analyses. Moreover, along with Munawir's idea of re-actualization, it has given rise to the controversies which are essentially focused on methodological problems. The extensive accommodation of customary values and practices is a good piece of the evident that the compilation is academically challenging. Obviously this accommodation of customs

\footnotetext{
${ }^{57}$ Similar cases actually have occurred in other Muslim countries, such as Morocco, Turkey and Egypt with rather different pattern and emphasis. On Morocco see Léon Buskens, "Islamic Commentaries and French Codes: The Confrontation and Accomodation of Two Forms of Textualization of Family law in Morocco", in Henk Driessen (ed.), The Politics of Ethnographic Reading and Writing: Confrontations of Western and Indigenous Views (Fort Lauderdale: Plantation, 1993), p. 65-100.On Turkey, see Murteza Bedir, "From Fikih to Law: Secularization through Curriculum", Journal of Islamic Law and Society, Vol. 11, No. 3, 2004, p. 378-401.

${ }^{58}$ For the recent and interesting analysis of this issue see M.B. Hooker and Tim Lindsey, "Public Faces of Shari'ah in Contemporary Indonesia: Towards a National Madzhab", p. 50-54.
} 
will characterize it generally as more empirical in orientation as opposed to textual orientation. At the same time, this accommodation also means the eclipse of the myth of Islamic law and custom (adat) clash. ${ }^{59}$ In contrast, it carries on its mission of promoting the peaceful relationship with custom at the level of legal and political policy as well as at the level of practical application. ${ }^{60}$

\section{E. Conclusion}

The re-actualization does not mean anything more than an intellectual exercise of which the purpose is to reproduce new interpretations of Islamic law of a more rationalistic character. In many ways, it fitted into the spirit and ideas which the two laws of the 1989 Religious Judicature Act and the Compilation wanted to convey. As it has been clear, these two laws depart radically from the traditional Islamic law bringing the former into line with the state positive law and its interests. Given this fact, it can convincingly be said that Munawir was willing to provide a type of Islamic law suitable to the nation state of Indonesia, which is a modern nation-state.

This state of mind is precisely what has given rise to the central issue in debates in the modern interpretation and discourse on Islamic law. It has not only been exercised through political means, but also reformulated to fit with the state's need of a well-oiled administration as well as the necessity of certainty in law. This is exactly what lay behind the idea of the re-actualization plus the 1989 Religious Judicature Act and the 1991 Compilation of Islamic Law. Together, these embodied the re-actualization of Islamic law in Indonesia under the New Order.

This study has shown that Munawir was fully and actively engaged in the making of Indonesian Islamic law discourse in the second half of the New Order era. The place and the role played by Munawir in the Indonesian political and legal systems is undoubtedly

\footnotetext{
${ }^{59}$ As stated earlier, the conflict approach between Islamic law and adat was commonly adopted by scholars in the period of colonialization.

${ }^{60} \mathrm{On}$ the fluctuating relationship between custom and Islamic law in Indonesia, see Ratno Lukito, Islamic Law and Adat Encounter The Experience of Indonesia (Jakarta: Logos, 2001).
} 
complex, for it relied on the intricate interactions between Muslims and the government and involved deep socio-religious sentiments. However, all his ideas and works consistently suggested a straight line of thinking. With Pancasila, Munawir convincingly played the role of a short of political engineer or to some extent that of a political broker, in the sense of Allen Smith's work, ${ }^{61}$ in making and implementing state policy. In his own context, this was to break down the politically distrustful relationship between Muslims and the state. The pivot of his role was then to provide political conditions which enabled both Muslims and the state apparatus to come to terms with each other. The result was the state accommodation of Muslim aspirations calling for the implementation of Islamic law. Unfortunately, it was the state then which took over the issue. The content of Islamic law and the way it was to be applied as a whole was made to fit in with the states style and administration.

An important role which was convincingly played by Munawir was that of "cultural broker", as used by Geertz, ${ }^{62}$ to bridge the culturally conceptual gap between Islamic law and state law. This role lies at the very centre of his ideas on the re-actualization. An examination of the re-actualization and the way of reasoning it offers have shown ideas and practices which departed from the traditionally constructed Islamic legal interpretation to bring it into line with the new circumstances in a modern state, Indonesia. Notwithstanding the fact that there have been objections, his re-actualization did indeed constitute the social construction and the political content of Islamic law from the viewpoint of the legal regime.

${ }^{61}$ James Allen Smith, The Idea Brokers: Think Tank and the Rise of the New Policy, Elite (New York: The Free Press, 1991), p. 8-14.

${ }^{62}$ Clifforrd Geertz, " The Javanese Kijaji: The Changing Role of a Cultural Broker", Comparative Studies in Society and History, vol. II, No. 2, 1960, p. 228-249. One should pay attention to the always-exist elements or resources of broker's role, that is power, knowledge, and the position a broker takes. For further discussion see Eric Wolf, "Aspects of Group Relations in a Complex Society", American Anthropologist, No. 6, 1956, p. 106. See also Szasz's introduction to his book, M.C. Szasz (ed.) Between Indian and White Worlds: The Cultural Broker (Norman OK: University of Oklahoma Press, 2001). 
Islamic law in Indonesia shares a number of similar problems with what has happened in other Muslim countries. There have been suggestions to influence or even to replace traditional Islamic jurisprudence and its interpretation with the state positive law. But the differential implementation of Islamic law in Indonesia has signified important features of the modern discourse of Islamic law. It can take it place alongside the state political and legal order, assuming a strong position and a culturally advanced appearance.

All this allows us to say safely that Munawir successfully played his role in contributing to the modern Islamic legal interpretation and discourse in Indonesia as a Muslim country. The position he took as well as the ideas he thought up can also be safely considered to have combined the dual functions of both of politics and culture or cultural broker, to emerge as the Indonesian Muslim spokesman before the government, while at the same time he hold office as a state-appointed Minister of Religious Affairs who was in charge of implementing the state's policies and interests. In the end, these all reflect the working process of the relationships between power and Islamic legal interpretation and knowledge of which Munawir himself was a part. 


\section{BIBLIOGRAPHY}

Abdullah, Abdul Gani, Pengantar Kompilasi Hukum Islam dalam Tata Hukum Indonesia, Jakarta: Gema Insani Press, 1994.

Abdullah, Taufik, "Menteri Agama Republik Indonesia: Sebuah Pengantar Profil Biografis", in Azyumardi Azra and Saiful Umam (eds.) Menteri-Menteri Agama RI Biografi Sosial-Politik, Jakarta: INIS, PPIM \& Badan Litbang Departemen Agama RI, 1998.

Adams, Wahiduddin, "Legislasi Hukum Islam dalam Perspective Fiqh", in Pesantren, No. 2, vol. II, 1990.

Arifin, Bustanul, "Kompilasi: Fiqh dalam Bahasa Undang-undang", in Journal of Pesantren, No. 2, vol. II, 1985.

------, Pelembagaan Hukum Islam di Indonesia Akar Sejarah dan Prospeknya, Cet. 1, (Jakarta: Gema Insani Press, 1996), p. 31-52.

Asmin, Yudian W. (ed.), Pengalaman Belajar Islam di Kanada, Yogyakarta: Titian Ilahi Press, 1997.

Bedir, Murteza, "From Fikih to Law: Secularization through Curriculum", Journal of Islamic Law and Society, Vol. 11, No. 3, 2004.

Bolland, B.J., The Struggle of Islam in Modern Indonesia, (The Hague: Martinus Nijhoff, 1982)

Bowen, John R., "Legal Reasoning and Public Discourse in Indonesian Islam", in Dale F. Eickelman and Jon W. Anderson, New Media in the Muslim World the Emerging Public Sphere, Bloomington \& Indianapolis: Indiana University Press, 1999.

Islamic Jurisprudence", in History of Religion, Vol. 38, No. 1, 1998, p. 73-78.

-------, "Shari'‘ without Fiqh: the Anthropology of Law without Law? Reflection from France", Paper presented at the ISIM Workshop on the Athropology of Islamic Law, Leiden, March 14-16, 2003.

-------, Islam, Law and Equality: an Anthropology of Public Reasoning, New York: Cambridge University Press, 2003. 
Buskens, Léon, "Islamic Commentaries and French Codes: The Confrontation and Accomodation of Two Forms of Textualization of Family Law in Morocco", in Henk Driessen (ed.), The Politics of Ethnographic Reading and Writing: Confrontations of Western and Indigenous Viens, Fort Lauderdale: Plantation, 1993.

Cammack, Mark, "Inching toward equality: Recent developments in Indonesian inheritance law", in Women Living Under Muslim Laws, Dossier 22, November 1999.

-------, “Indonesia's 1989 Religious Judicature Act: Islamization of Indonesia or Indonesianization of Islam?", Cornell Southeast Asia Programm, No. 63, 1997.

Effendy, Bahtiar, "Islam and the State in Indonesia: Munawir Sjadzali and the Development of a New Theological Underpinning of Political Islam", in Studia Islamica Indonesian Journal for Islamic Studies, Vol. II, No. 2, 1995.

-------, "Islam Negara di Indonesia: Munawir Sjadzali dan Pengembangan Dasar-dasar Teologi Baru Politik Islam", in Muhammad Wahyuni Nafis et. all (eds.), Kontekstualisasi Ajaran Islam 70 Tahun Prof. Dr. H. Munawir Sjadzali, MA, Jakarta: Paramadina, 1995.

Federspiel, Howard, "Islamic Values, Law and Expectations in Contemporary Indonesia", in Arskal Salim and Azyumardi Azra (ed.), Shari'a and Politics in Modern Indonesia, Singapore: ISEAS, 2003.

Feener, R. Michael, Developments of Muslim Jurisprudence in Twentieth Century Indonesia, Ph.D Dissertation submitted to the Boston University, 1999.

Geertz, Clifforrd, "The Javanese Kijaji: The Changing Role of a Cultural Broker", Comparative Studies in Society and History, vol. II, No. 2, 1960.

Hamim, Taha, Moenawar Chalil's Reformist Thought: A Study of An Indonesian Religious Scholars (1908-1961), Ph.D. Dissertation, McGill University, Montral Canada, 1996. 
Harahap, M. Yahya "Informasi Kompilasi Hukum Islam: Mempositifkan Abstraksi Hukum Islam”, in Cik Hasan Bisri (ed.), Kompilasi Hukum Islam dan Peradilan Agama dalam Sistem Hukum Nasional, Jakarta: Logos, 1999.

, Kedudukan Kewenangan dan Acara Peradilan Agama Menurut Undang-undang No. 7 tahun 1989, Jakarta: Pustaka Kartini, 1989.

Hisyam, Muhamad, Canght Between Three Fires The Javanese Pengulu Under The Dutch Colonial Administration, Jakarta: INIS, Vol. 37, 2001.

Hooker, M.B., "The State and Shari'a in Indonesia", in Arskal Salim and Azyumardi Azra, Shari'a and Politics in Modern Indonesia, Singapore: Institute of Southeast Asian Studies, 2003.

-------, and Tim Lindsey, "Public Faces of Shari'ah in Contemporary Indonesia: Towards a National Madz̧ab", Journal Studia Islamika, Vol. 10. No.1, 2003.

Hoosen, Ibrahim, "Beberapa Catatan tentang Reaktualisasi Hukum Islam", in Muhammad Wahyuni Nafis et.al. (eds.), Kontekstualisasi Ajaran Islam 70 Tabun Prof. Dr. H. Munawir Sjadzali,MA., Jakarta: IPHI-Paramadina, 1995..

Ismail, Faisal, "Munawir Sjadzali dan Pemikiran Politik Islam Kontemporer di Indonesia”, Mukaddimah, No. 3, July, 1997

Jabali, Fuad, and Jamhari et.al. (ed.), IAIN dan Modernisasi Islam di Indonesia, Jakarta: Logos, 2002.

Layish, Aharon, “The Transformation of the Shari'a from Jurists' Law to Statutory Law in the Contemporary Muslim World", Die Welt Des Islam, vol. 44, no.1, 2004.

Lev, Daniel S., Islamic Court in Indonesia: A Study in the Political Bases of Legal Institutions, (Berkeley: University of California Press, 1972)

Lukito, Ratno, Islamic Law and Adat Encounter The Experience of Indonesia, Jakarta: Logos, 2001.

Maarif, A. Syafi'I (et.al), Syariat Islam Yes Syariat Islam No Dilema Piagam Jakarta dalam Amandemen UUD 1945, Jakarta: Paramadina, 2001. --------, Studi tentang Percaturan dalam Konstituante Islam dan Masalah Kenegaraan, Jakarta: LP3ES, 1985. 
Madjid, Nurcholish, "Prof. Dr. Munawir Sjadzali, Antara Diplomasi dan Tugas Kyai", in Muhammad Wahyuni Nafis et.all (eds.), Kontekstualisasi Ajaran Islam 70 Tahun Prof. Dr. H. Munawir Sjadzali,MA., Jakarta: IPHI-Paramadina, 1995.

Mawardi, Ahmad Imam, "The Political Backdrop of the Enactment of the Compilation of Islamic Laws in Indonesia", in Arskal Salim and Azyumardi Azra, Shari'a and Politics in Modern Indonesia, Singapore: Institute of Southeast Asian Studies, 2003

Mubarok, Acep Zoni Saiful, Kompilasi Hukum Islam sebagai Sumber Hukum (Study kasus di Pengadilan Agama Tasikmalaya), MA Thesis submitted to the post-graduate programme of the state institute for Islamic studies Sunan Kalijaga Yogyakarta, 2000.

Mudzhar, Mohammad Atho, Fatwas of The Council of Indonesian Ulama: A Study of Islamic Legal Thought in Indonesia 1975-1988, Jakarta, INIS Vol. XVII, 1993.

Mursyid, Hasbullah, "Menelusuri Faktor Sosial yang Mungkin Berpengaruh", in Muhammad Wahyuni Nafis,et.al. (eds.), Kontekstualisasi Ajaran Islam 70 Tahun Prof. Dr. Munawir Sjadzali,MA. (Jakarta: Paramadina-IPHI, 1995)

Muslimin, J.M., The Reactualization of Islamic Law : A Study of Trends and Methods of Islamic Legal Reform in Indonesia (1945-1995), MA Thesis Submitted to Leiden University, 1998.

Rahardjo, M. Dawam, "Kecendekiawanan dan Masalah Legitimasi Politik di Indonesia”, Muhammad Wahyuni Nafis et.all (eds.), Kontekstualisasi Ajaran Islam 70 Tahun Prof. Dr. H. Munawir Sjadzali,MA., Jakarta: IPHI-Paramadina, 1995.

Rasyid, Roihan A., "Pengganti Ahli Waris dan Wasiat Wajib" in Cik Hasan Bisri (ed.), Kompilasi Hukum Islam dan Peradilan Agama dalam Sistem Hukum Nasional, Jakarta: Logos, 1999.

--------, Hukum Acara Peradilan Agama, Jakarta: Rajawali Pers, 2002.

Sjadzali, Munawir, "Aspirasi Umat Islam Terpenuhi Tanpa Partai Islam", in Islam: Realitas Baru dan Orientasi Masa Depan Bangsa, Jakarta: Universitas Indonesia Press, 1993. 
Cipto Sembodo

"Asas Pancasila, Aspirasi Umat Islam dan Masa Depan Bangsa" Wawancara Khusus Harian Umum Pelita dengan H. Munawir Sjadzali MA, Jakarta: 1986.

, "Dari Lembah Kemiskinan", in Muhammad Wahyuni Nafis et.all (eds.), Kontekstualisasi Ajaran Islam 70 Tabun Prof. Dr. H. Munawir Sjadzali,MA., Jakarta: IPHI-Paramadina, 1995.

--------, “Gejala Krisis Integritas Ilmiah di Kalangan Ilmuwan Islam” in Islam: Realitas Baru dan Orientasi Masa Depan Bangsa, Jakarta: Universitas Indonesia Press, 1993.

--------, "Ijtihad dan Kemaslahatan Umat", Haidar Bagir and Syafiq Basri (ed.), Ijtihad dalam Sorotan, Bandung: Mizan, 1988.

--------, "Keynote Address to the United Nations University Exploratory Seminar on Islam and Non-Violence", in Munawir Sjadzali, Islam Realitas Baru dan Orientasi Masa Depan Bangsa, Jakarta: Universitas Indonesia Press, 1993.

--------, "Landasan Pemikiran Politik Hukum Islam Dalam Menentukan Peradilan Agama di Indonesia", in Eddy Rudiana Aried et.al. (ed.), Hukum Islam di Indonesia Pemikiran dan Praktek, Bandung: Rosdakarya, 1991.

--------, "Pembangunan Hukum dan Perkembangan Fiqh di Indonesia", in Islam Orientasi Baru dan Orientasi Masa Depan Bangsa, Jakarta: Universitas Indonesia, 1993.

--------, "Pancasila as an Islamic Ideology for Indonesian Muslims", Interview with Munawir Sjadzali, in Studia Islamika, Vol. 1, No. 1, 1994.

-, “Reaktualisasi Ajaran Islam”, Eddi Rudiana Arief (ed.), Hukum Islam di Indonesia Pemikiran dan Praktek, Bandung: Rosdakarya, 1994.

--------, “Reaktualisasi Ajaran Islam”, Iqbal Abrurrauf Saimima, Polemik Reaktualisasi Ajaran Islam, Jakarta: Pustaka Panjimas, 1988.

--------, "Relevansi Hukum Keluarga Islam dengan Kebutuhan Masa Kini”, in Amrullah Ahmad et.al. (ed.), Prospek Hukum Islam dalam Kerangka Pembangunan Hukum Nasional di Indonesia Sebuah Kenangan 65 tahun Prof. Dr. H. Bustanul Arifi, SH., Jakarta: PP-IKAHA, 1994. 
-------, “Syariah: A Dynamic Legal System", Keynote address to the international seminar on shariah and codification, Colombo, December $16^{\text {th }}$ 1985. Himpunan Pidato Menteri Agama RI H. Munawir Sjadzali Oktober 1985-September 1986, Biro Hukum dan Humas Departemen Agama RI.

--------, "The Role of the Muslim Religious Leader (Ulama) in the Solution of the Population Problems Indonesia Experience", in Islam: Realitas Baru dan Orientasi Masa Depan Bangsa, Jakarta: Universitas Indonesia Press, 1993.

-------, Ijtihad Kemanusiaan, Jakarta: Paramadina, 1997.

-------, Islam and Governmental System, Jakarta: INIS, 1991.

--------, Islam dan Tata Negara: Ajaran, Sejarah dan Pemikiran, Jakarta: Universitas Indonesia Press, 1990.

--------, Muslims 'Interests Are Better Served in the Absence of Muslim Parties, Jakarta: Department of Religious Affairs, 1992.

Smith, James Allen, The Idea Brokers: Think Tank and the Rise of the New Policy, Elite, New York: The Free Press, 1991.

Smith, Judith G., Political Broker: People, Organization, Money and Power, New York: Live right, 1972.

Steenbrink, Karel A., Beberapa Aspek tentang Islam di Indonesia Abad Ke19, Jakarta: Bulan Bintang, 1984.

-------, Pesantren Madrasah Sekolah Pendidikan Islam dalam Kurun Modern, Jakarta: LP3ES, 1986.

Szasz, M.C., (ed.) Between Indian and White Worlds: The Cultural Broker, Norman OK: University of Oklahoma Press, 2001.

Wolf, Eric, "Aspects of Group Relations in a Complex Society", American Anthropologist, No. 6, 1956. 